\title{
A Reflection on the Islamic Portrait of Jesus
}

\author{
Kolawole Oladotun Paul \\ Department of Theology, ECWA Theological College Kpada, Nigeria \\ Dotunpaul98@gmail.com \\ Doi: https://doi.org/10.46222/pharosjot.10309
}

\begin{abstract}
When the name 'Jesus' is mentioned, one's instant thought turns towards Christianity. Discourses on Jesus are made often with reference to Christendom. No doubt, Christianity has volumes to say about God and man; crucial claims are made about the meanings of life and the significance of death. The distinctive nature isn't only about these crucial insights, but the process in which they were known. The Christian faith is based on the personhood of Jesus Christ. This is because the Christian understanding of God and man arises from the Christian understanding of the identity of Jesus Christ as a God-man. There have been several attempts by scholars to study the person and importance of Jesus. Nevertheless, a Christian searches the Bible for answers. This article takes a wide angle lens in the sense that its periscope includes the Quranic account of Jesus with the aim of ascertaining Jesus' identity. Jesus is confirmed by both religion and non-religious historians to have lived historically. Christians adhere strictly to the messianic role and other significant theological events like the cross which upholds the Christian faith, but, Islam presents Jesus as a man (though with high honour and relevance) who lived specially as a prophetic bridge leading to Prophet Muhammad. Therefore, Islam makes it extremely necessary to emphasize and re-emphasize the fact that Jesus Christ, the Messiah did not come merely to teach and heal, but to redeem people from their sins.
\end{abstract}

Keywords: Bible, Christian, Islam, Jesus, Muhammad, Muslim.

\section{Introduction}

No Muslim is a true Muslim unless he believes in Jesus (the one who is already blessed) as an Apostle of Allah. Muslims inherently presents this at the forefront of any discussion with Christians about the personhood of Jesus Christ. The dignity awarded to Jesus is very high - even when Muhammad's name is mentioned, Muslims say "may God's prayers and peace be upon him". This connotes that Muslims pray for Muhammad whenever his name is mentioned, regardless of the number of times, but Jesus is referred to as one who is already blessed. Swansea asserts that Muslims have always been suspicious in the ways in which Christians talks about Jesus; why do Christians make divine claims for this beloved Prophet and Apostle of Allah? (Swanson, 2002) ${ }^{1}$ How can it be that such an honoured prophet and beloved apostle of God should die the ignominious death of crucifixion? Is it not God's custom to save his apostles as he saved Noah, Abaraham, Lot and Moses? (Watt, 1970) ${ }^{2}$ The focus of this study is to explore the Islamic view of Jesus. This research underscores the communalities and differences between the Qur'an and apostolic interpretations of the Bible in the Gospels and Epistles (Bell, 2017). ${ }^{3}$ Also, this research

\footnotetext{
${ }^{1}$ Mark N. Swanson, (2002). "Thinking through Islam". Word and World, Volume 22:3; Spring, 170.

2 W. Montgomery Watt, (1970). Bell's Introduction to the Qur'an (Edinburgh: University Press, 127.

${ }^{3}$ Few objective Muslim scholars encourage and have even walked this path. Akyol, a visiting fellow at the Freedom Project at Wellesley college in Massachusetts calls on Muslims to spend more time learning about
} 
clarifies misunderstanding; such that it inquires whether the Quranic Jesus is amendable to the biblical elements that give Jesus uniqueness and centrality in the Christian faith.

The Jesus of The Qur'an reflects many of the characteristics of the communities that had found a home in the Arabian Peninsula - from his name, 'Isa' (an apparent corruption of the one used by the Syriac Christians), to his nature as Prophet but not divine (Dudely, 1996). ${ }^{4}$ Muslims are quick to demonstrate charity for Jesus and his mother Mary; "Son of Mary was simply an apostle. Apostles before him have passed away! His mother was a woman of truth, both of them took food" (Cragg, 1995). ${ }^{5}$ The Qur'an has a whole chapter about Mary, who is the only woman mentioned by name in the Holy Book. Jesus' name occurs several times in the Qur'an without recognition to Him as the 'Messiah' - in the context of the Christian's understanding as 'Christ'. If one looks past the superficial politically correct desire for unity, the difference between Islam and Christian view of Jesus are vast and fundamental (Caner \& Caner, 2002). ${ }^{6}$ The Qur'an narrated that Jesus started speaking on the day he was born. This is far-fetched and not so appealing to logical mind; thus, it's regarded as more or less mythological. A high view of Jesus does not necessarily mean a correct view (Ali, 1999). ${ }^{7}$

Islam greatly emphasizes the virgin birth of Jesus and the fact that he preached the truth (Kolawole, 2021). ${ }^{8}$ The content of the truth was however channelled to Muhammad, who is from the lineage of Abraham and Ishmael (Cahill, 1998). ${ }^{9}$ Christians also believe that Jesus was born to a virgin, but differ significantly when it is said that Jesus is the truth (Kolawole, 2020). ${ }^{10}$ This is a claim of Jesus himself - "...I am the way, the Truth and the Life; no one comes to the Father except through me" (John 14:6). This connotes that Jesus was not an example of righteousness but the sacrifice through which man obtains righteousness (Kolawole, 2019). ${ }^{11}$ On this note, the difference between Muslims and Christians are proportional to the importance of the cross in human salvation and atonement with God the Father.

Jesus by grasping the New Testament. He further admit that calling on Muslims to spend more time thinking about Jesus and even reading Christian Scripture might be too much for some Muslims; but this is what the Quran itself advocates. Matthew Bell, (2017). "Muslims revere Jesus too but this Turkish Author sees Jesus in a new light", The Word; July. www.google.com/amp/s/www.pri.org/stories/2017-07-31/muslimsrevere-jesus-new-light\%3famp

${ }^{4}$ Woodberry J. Dudely, (1996), "The Muslim Understanding of Jesus". Word and World, Volume XVI: 2, Spring, 173.

${ }^{5}$ The Quranic passages are conveniently gathered together and interpreted in English by Kenneth Cragg, (1995). Readings in the Qur'an (London: Fount Paperbacks, 163-171.

${ }^{6}$ Caner Ergun M. and Caner, Emir F. (2002), Unveiling Islam. Nassarawa: Evangel Publishers, 213.

${ }^{7}$ Ali, M. (1999), Islam Reviewed. Fort Myers: Fish House Publishing, 34.

8 Oladotun Paul Kolawole, (2021). "Proclaiming the Christian Gospel to Muslims", John W. Carter [Ed.], Light in a Once Dark World: Contemporary Issues in Nigerian Christianity, Volume IV. Hayesville:

American Journal of Biblical Theology, 245-258.

9 Thomas Cahill, (1998). The Gifts of the Jews: How a Tribe Desert Nomads Changed the Way Everyone Thinks and Feels. Doubleday: Nan A. Talase, 9.

10 Paul Oladotun Kolawole, (2020), "The Central Theme of John's Gospel and the Christian Community", Asia Pacific Journal of Academic Research in Social Sciences, Vol. 5 [May] No. 1. Batangas City, Philippines: Lyceum of the Philippines University, 57-61.

${ }^{11}$ Kolawole Oladotun Paul, (2019), "A Critical Examination of the Concept of Righteousness in Matthew," Asia-Africa Journal of Mission and Ministry Vol. 20, August 31. Hwarangro Nowon-gu, Seoul: Mission and Society Research Institute, Sahmyook University, 96-106. 


\section{The Prominence of Jesus}

The birth narrative of Jesus in the Qur'an begins with Sura 19: 16-34. Synonymous to the biblical account, the Quran presents the birth of Jesus often with the prologue describing the character of Mary, her service in the temple under the care of priest Zachariah who was to be the father of John the Baptist. "I am God's servant, he has given me the book and made me a prophet, he has made me blessed wherever I am and has enjoined on me, worship and alms, so long as I like and to be dutiful to any mother. And has not made me oppressive and impious peace on me the day I was born the day I shall die and the day I shall be raised alive." Schumann (2002) argued that the speaking infant theme is found in the Syriac Infancy Gospel, a Pre-Islamic sixth-century work. ${ }^{12}$ Over the centuries, this narrative has been recounted with certain variations and detailed additions by Islamic historians (Neal, 1991). ${ }^{13}$ Islamic theology affirms Mary as a pure vessel, but denies the Immaculate Conception as uphold by some Christian traditions. The message and declaration of angel Gabriel also reflects in the birth of Jesus.

According to Michael (1983), Jesus is often referred to as 'Issa Ibn Maryam' - Jesus son of Mary. ${ }^{14}$ $\mathrm{He}$ is also called 'Issa Masih'; Jesus the Messiah - this implies that he is the penultimate prophet, messenger of God (Allah) and Messiah. 'Masih' is the Arabic word for Messiah; however, this Messianic concept differs from Christian's understanding. None of the usage of 'Masih' in association with the Quranic connotes redemption. Muslims explain 'Masih' in several ways; they commonly link the word in Arabic to mean 'wander' or 'travel far'; Jesus is seen as a wanderer who had an itinerant ministry without a place to lay his head. Another usage of the word is in terms of 'touch' and 'anoint'; Muslims link the word to Jesus' act of healing the sick and lepers, such that he often pass his hands over them. These explanations do not have any historical and redemptive development unlike the biblical record.

According to Moucarry (2002) quoting Zwemer (1912), there have been several speculations about the origin of the name 'Issa' as used for Jesus in the Qur'an. Some Western scholars explain it as a corruption of the name "Esau", due to the misinformation given to Muhammad by the Jews; whose hostility to Jesus brought about this deception. ${ }^{15}$ It sounds more like the Miriam of the Old Testament was misunderstood and mistaken for Mary the mother of Jesus. Another school of thought argues that Muhammad inverse the Hebrew consonants of the redemptive name (Yesu'ah - which means Yahweh saves). Meanwhile, a simple inversion of the letters does not produce Issa. Another stance is that Issa is an Arabic derivation, though unusual from the Greek rather than Hebrew, combined with imitation of Muss (Moses). These standpoints as stated are probe-able; any argument in this stead must be harmonious with the fact that Qur'an fosters a genuine esteem for Jesus and His mother. However, Issa bears none of the biblical connotations associated with Jesus (God saves), the saviour, because the biblical Jesus is "Emmanuel" - God with us (Matthew 1:21; Isaiah 8:4)

The significance and prominence of Jesus in Islam is reflected in his being mentioned in the Qur'an in ninety-three verses with various titles attached - 'Son of Mary', 'Spirit of God', and 'Word of God' (Geoffrey, 1965). ${ }^{16}$ The Qur'an also uses the word 'servant' (or slave) to describe Jesus;

12 Olaf H. Schumann, (2002), Jesus the Messiah in Muslim Thought. Delhi: ISPCK, 14.

${ }^{13}$ Robinson Neal, (1991), Christ in Islam and Christianity. Oxford: Oxford University Press, 12.

14 Cook Michael, (1983), Muhammad (Oxford: University Press, 32.

${ }^{15}$ C.G. Moucarry, (2002), The Prophets and the Messiah: An Arab Christian Perspective on Islam and Christianity (Illinois: Inter Varsity Press, 14. S.M. Zwemer, (1912). The Muslim Jesus (Edinburgh:

Anderson and Femier,

${ }^{16}$ Parrinder Geoffrey, (1965), Jesus in Quran. London: Oxford One World Publication, 33. 
"He is nothing but a slave on whom we bestowed favour, and we made an example for the children of Israel." 'Servant' is the creature status-quo of Jesus, yet there is something unique in his perfect obedience, such that he is an example for the people. The biblical usage of servanthood in relation to Jesus depicts more explicitly. This stance is absolutely within the confine of the historic and redemptive context. Jesus' servanthood was essential because it was the means through which he expressed his solidarity with his people (Kolawole, 2021). ${ }^{17} \mathrm{He}$ identified completely with humanity in order to accomplish a substitutionary atoning work on their behalf, as the representative of his people (Isaiah 52:13-53, Matthew 3:17, Mark 10:45).

Muslim explain the view of Jesus as the Son of God in two ways; the first has to do with Jesus' birth which is a result of God's creative command, compared to that of Adam (Sura 3:59). The second is on the premise that Jesus proclaimed the Word of God with power, accompanied by many signs (Kolawole, 2021). ${ }^{18}$ However, since Adam's birth was similar to that of Jesus, why wasn't he called the word of God? The Muslims strongly believe that the word of God have come down to mankind in form of a book; meanwhile, in the Bible the Word has become flesh (incarnate) (Jacob \& Kolawole, 2020). ${ }^{19}$ Also, the preaching of Muhammad was said to be powerful, why was he not referred to as the word of God? McDowell (2002) explained that Jesus is presented with other relational titles; mentioned directly or indirectly over 187 times by the name Issa third persons - 48 times first person - 35 times and the rest of the titles. ${ }^{20}$ If Qur'an were to be an academic paper, the name Jesus would have been part of the keywords.

For Muslims, the only adequate and authoritative presentation of Jesus is the one given in the Qur'an (Michael, 1983). ${ }^{21}$ Jesus is believed to be one of the prominent and divinely ordained prophets of Allah to preach and lead people on the straight path. The prophethood of Jesus is in the order of Abraham, Ishmael, Noah and Moses. It is often emphasized that the Injeel is entrusted to Jesus and he confirms the Torah given to Moses. Unfortunately, Quranic Jesus confirms very limited amount of the Old Testament revelation, which can be summarized thus: 'There is only one God who is creator, all powerful and universal legislator.

He speaks through the prophets, and he rewards mankind according to works on the day of judgement'. With this, it is logical to say that Jesus preaches the monotheistic doctrines of Islam available to him. The Qur'an and Hadith's mentioned Jesus to be born pure (without sin) by Maryam, but denies Jesus as deity, especially quoted is Sura 5:116 where Jesus refutes the claim of being divine (Obasola, Oderinde \& Akanni, 2020). ${ }^{22}$ The prominence of Jesus centres on the point that he is the precursor to the Islamic prophet Muhammad. Muslims argue that the coming of Muhammad was predicted by Jesus. Therefore, early Arab Muslims claim legitimacy for their faith in the existing religious traditions and the alleged predictions of Jesus.

\footnotetext{
17 Kolawole Oladotun Paul, (2021), Leadership Pattern of Jesus in John 13:1-17. Its Relevance in the Nigerian Church and Society. Vidyajyoti Journal of Theological Reflection, 85 (7), July, 524-536

${ }^{18}$ Kolawole, "Proclaiming the Christian Gospel to Muslims", 256.

19 Jacob Peter Oluwashola \& Kolawole Oladotun Paul, (2020), "Is the Bible the Word of God? A TheoApologetical Rethink", Pharos Journal of Theology, volume 101, no 4 3-4.

20 J.J. McDowell, (2002), Understanding Islam and Christianity: Belief that Separates us and How to talk about them. Oregon: Harvest House Publications, 12.

${ }^{21}$ Michael, Muhammad, 52.

${ }^{22}$ Kehinde Emmanuel Obasola, Olatundun Abosede Oderinde \& Akeem Adebayo Akanni, (2020), "Islam's Response to the Quest for Peace, Orderliness and Well-being in Nigeria", A Festschrift in Honour of Prof. Kamaldeen Abdulazeez Balogun (ljebu Ode: Alamsek Gen Concept, 53.
} 


\section{The Nature of Man and Salvation}

The Islamic concept of revelation has no room for the Christian understanding of the 'Gospel' as the 'good news' (given to utterly lost mankind) (Kolawole, 2021). ${ }^{23}$ Therefore, the content of the gospel (injeel) of Jesus is simply a series of law, in which by knowing this law, man may practice it and win the favour of Allah and earn his salvation. In fact, the word salvation - 'najat' was used only once in the Quran. The injeel is understood in Islam as a book which descended from heaven on the messiah. ${ }^{24} \mathrm{He}$ simply received it and was commissioned to preach it to the children of Israel; but there is no word at all about redemption. Christians believe that the good news is not just attributed to Jesus the Messiah, but also God the Father. This then reveals the Bible as the Gospel of God and the Gospel of the Son (Jacob \& Kolawole, 2020). ${ }^{25}$

With the mention of God's Son, Christian and Muslims immediately reach cross-roadS. Islam sees the Christian definition of Gospel as blasphemy (Shirk in Arabic). Surat At-atubah 30: "...the Christians call Christ the son of God. That is a saying from their mouth. (in this) they but imitate what the unbelievers if old use, God' curse be upon them." A particular Muslim confusion is that the Christian "Trinity" consists of the Father, Son, and Mary. Kolawole argued that this misunderstanding stems from pre-Islamic polytheism in Arabia, where it is believed that God could have a wife or wives (Kolawole, 2021). ${ }^{26}$ Also, the problem here is probably related to historic assertions of Monophysite Christianity between the fifth and seventh centuries. The affirmation of Cyrillian Christianity that Jesus had only one nature, coupled with a developing devotion to Mary, ended in her being declared Theotokos, "The God's bearer" or the "Mother of God." Since in Syria, Egypt, and Arabia, Christianity was represented in the form of Monophysism, it was probably this formulation that influenced Muhammad's understanding.

The Qur'an presents God as a lonely being in a Unitarian way. Therefore, how can He have a Son? He does not beget, neither is He begotten. This argument forms an important part as discussed in the later part of this research. Shirk means a worst concept of sin a person can commit regarding the God-head i.e. associating partners with God. Islam situates this on their understanding of the call of Abraham. This standpoint is in a pure ethnic lens just like the Jews. They view this great Patriarch as an end in himself; thus, his dignity is transferred to the Arabs, the descendants through Ishmael and later on to Muhammad. For the Muslim, Christology is not included in theology; whereas, for the Christian it is central to theology. Incarnation is impossible in Islam, but the ultimate form of prophethood in Christianity is for the Word to be expressed in the flesh (Otunnaya \& Kolawole, 2021). ${ }^{27}$ In Jerusalem, on the ancient temple mount of God most holy, Abd al-malik Ibn Marwan in 688 CE built the dome of the rock as a memorial to Muhammad. The dome was erected just 300 feet south of where the Solomonic temple stood and only a few hundred yards away from where Jesus was crucified. Within the dome is a prominent inscription in Arabic that reads: "God forbids that he should have a son" (Ali, 1999). ${ }^{28}$

${ }^{23}$ Kolawole, A Christian Perspective of the Rise of Islam, 24.

${ }^{24}$ In the Arabic version of the letters to the Romans, the word injee/ was used for good news. In this stance, Arab Christians understands Injeel as what God decided to do concerning the redemption of man and how it became an accomplished fact through the incarnation of the Son of God, his suffering, his death and his glorious resurrection.

25 Jacob \& Oladotun, "Is the Bible the Word of God?

${ }^{26}$ Kolawole, A Christian Perspective of the Rise of Islam, 25.

${ }^{27}$ Otunaya Abdulazeez \& Kolawole Oladotun Paul, "The Relevance of John 1:1-18 For Contemporary Christians" Vidyajyoti Journal of Theological Reflection, Vol. 85:3 March, (2021), 176-209.

${ }^{28} \mathrm{Ali}$, Islam Reviewed, 11. 
Muslims believe that since man is suffering from ignorance, he doesn't need the righteousness of God; rather he simply needs the will of God (Kolawole, 2021). ${ }^{29}$ The nature of man as revealed by Islam is that man needs to know the will of Allah and by doing so he may please God. The revelation of God's will is enough to save man. Through this enlightenment, man is enabled to fulfil all the requirements of the divine will. Therefore, man does not need a saviour because he is simply a weak creature; all he needs to do is simply adhere to the will of Allah. Unlike Christians, Muslims reserve the word 'Rab' - Lord for Allah alone; Islam sees Jesus as a mere prophet and apostle, nothing else. Since the Qur'an portrays the human predicament as primarily ignorance rather than evil, as in the biblical analysis, the Muslims see only the need of a guide, not a saviour.

\section{Jesus and His Own Identity}

Muslims credit Jesus with miraculous deeds; he was recorded to perform miracles when he was a mere baby. The Qur'an recorded that Jesus spoke on the day he was born (during cradle); he also made birds from the mud and fly in the air (Sura 3:49). This account reflects 'The Infancy Story of Thomas'; though a bit different because here, Jesus heals the blind, the leper and even raises the dead, but always with the permission of God (Hennecke, 1973). ${ }^{30}$ The biblical miracles of Jesus were meant to prove that Christ was sent from God and that He had specific divine mission to seek and save the lost. The mission of Jesus Christ is redemptive; but the miracles attributed to Jesus in the Qur'an do not fulfil these requirements. In view of this, Ali argued that miracles of Jesus are more of mythological nature in the Qur'an (Ali, 1999). ${ }^{31}$

The Qur'an relates Jesus' understanding of himself and his mission while still in the cradle. Shortly after birth, Jesus protected his mother who was accused of adultery by her people. The prophetic proclamation of Jesus is instructive; depicting that Jesus is God's slave, chosen by God's true and sovereign grace to do his bidding. Jesus condemns idolatry, and fosters the practice of God, discouraging what is evil. God's revelation to Muhammad is seen as that which supersedes all other prophets including Jesus. Therefore, it was not necessary to repeat in great detail what has been previously revealed. This forms the bedrock for the sketchy and repetitive character of the Quranic portrayal of Jesus.

Matthew 16:13-17 is cardinal to Jesus' identity: "Now when Jesus came into the parts of Caesarea Philippi, he asked his disciples, saying, Who do men say that the Son of man is? And they said, Some say John the Baptist; some, Elijah; and others, Jeremiah, or one of the prophets. ${ }^{15} \mathrm{He}$ saith unto them, But who say ye that I am?And Simon Peter answered and said, Thou art the Christ, the Son of the living God. And Jesus answered and said unto him, Blessed art thou, Simon Barjonah: for flesh and blood hath not revealed it unto thee, but my Father who is in heaven." During the biblical narrative time, there was tension concerning the person of Jesus Christ. The Messiah himself was aware and that is why he asked the question about his identity. Jesus posed two questions; who do people say I am? Then, who do you (referring to the disciples) say I am? The first question reveals that Jesus is aware of people's differing opinions about Him. Anyone could think of Jesus' ministry as anything, but this does not mean that such opinion is genuine. The frequent amazement of the crowd towards Jesus' authority and in words (Matthew 4:24, 7:28-29, $9: 8,26,13: 54,15: 31)$ reveals that Jesus must have been referred to by several names among the people (France, 2008). ${ }^{32}$ Several names and news must have been flying around during Jesus' time. Thus, Jesus sees the need to address the issue in a discourse with the disciples.

\footnotetext{
${ }^{29}$ Kolawole, A Christian Perspective of the Rise of Islam, 23-24.

${ }^{30}$ E. Hennecke, New Testament Apocrypha (London: SCM, 1973), 1:392-393.

${ }^{31}$ Ali, Islam Reviewed, 55.

${ }^{32}$ R.T. France, Matthew: Tyndale New Testament Commentaries (Michigan: IV P, 2008), 54.
} 
From the biblical text, it is clear that the real identity of Jesus Christ cannot be known by flesh or blood (human knowledge, philosophy, understanding or calculation). This connotes that any revelation or explanation outside the realm of the Holy Spirit will only provide man with a blurred picture which is not the real identity of Jesus. In other words, education, exposure and meditations cannot substitute the revelation of the Holy Spirit. Jesus had to ask His disciples to affirm this true confession so that they would not follow some among the crowd who only saw Jesus as one of the prophets, not necessarily the Messiah. The writings and collections of the New Testament did not do away with the Old Testament documents; rather, they form an integral part of the unique book from beginning to the end. How appropriate and sequential it would have been is Muslims had included all the previous scriptures with the Qur'an to allow for proper reading and comparison.

\section{Muhammad's Stance on Jesus' Sonship}

The term "Son of God" is not a Christian invention. Instead, it was indeed what Jesus knew himself to be. The Pharisees in Jesus' day fully understood that Jesus declared his sonship and attempted to kill him for it several times. The disciple's responses to the first question gives the identity of Jesus as a prophet and in the order of several prophets that existed, who even spoke about Him (Isaiah, Jeremiah, John among others). From these responses, the opinion of the people is in two distinct stances; the first one says Jesus is John, Isaiah, Jeremiah while the second says Jesus is one of the prophets. This scenario is suggestive of the fact that using human effort to comprehend the true identity of Jesus will remain abortive.

The true identity of Christ can only be confirmed and affirmed by revelation, not hallucination or demonic possession. God the father chose the young girl Mary of Nazareth (a virgin) to bear the child (Luke 1:28). Jesus Christ was born, receiving Mary's fully human nature and the lineage of King David (Zaka \& Coleman, 2004). ${ }^{33}$ Completing the miracle, Jesus Christ inherited the divine nature of the heavenly father. How possible is this? The father is holy; neither can sin abide in his presence nor can it endures in the person of the Son (Aremu \& Malomo, 2015). ${ }^{34}$ Therefore, the corruption of original sin which resulted from Adam's fall was never found in Jesus Christ.

Muhammad only conceived Jesus as the son of Mary, no more than a messenger. He charged the thought of Jesus taking God's nature as shirk (blasphemy). Although Jesus is referred to as Al-Masih (Messiah), Muhammad explained it to mean the anointed one and nothing more, just like Rasul which means messenger or apostle. Muhammad merged known pre-Islamic legends with mishmash heretical books and misunderstood biblical materials (Griffith, 1979). ${ }^{35} \mathrm{He}$ was then able to deliver the scripture like message to and for the people of Arabia. He became the "Arabian prophet" bringing Allah's final and definite message to the world through those who would come to be known as the descendants of Ishmael (Zaka \& Coleman, 2004). ${ }^{36}$

One does not strive to be a son; it is rather one is a son or not. Sonship occurs through natural generation or adoption. The Bible maintains that Jesus is the only begotten of the father (John

${ }^{33}$ Zaka, A. and Coleman, D. The Noble Quran's Teachings in the Light of the Holy Bible (New Jersey: R and R Publishers, 2004), 58.

${ }^{34}$ Tunde Aremu and Emmanuel O. Malomo, Christian Theology in African Context (Ilorin: Amazing Grace Prints, 2015), 37.

${ }^{35}$ Sidney H. Griffith, "Comparative Religion in the Apologetics of the First Christian Arabic Theologians," Proceedings of the PMR Conference, vol. 4 (1979) 63-87.

${ }^{36}$ Zaka, and Coleman, The Noble Quran's Teachings in the Light of the Holy Bible, 36. 
3:16); yet, God is a Spirit and his nature displays divine attributes unique to Him and he is one essence of a trinitarian Godhead (Ware, 2004; Nicolaides, 2010). ${ }^{37}$ Muhammad's conception of Jesus is an excerpt of the above quoted biblical text. Swanson explained that there was no doubt that Muhammad admired both Jews and Christians (Swanson, 2002). ${ }^{38}$ The fact that Jesus had a long line of divinely appointed individuals occupying the prophetic office was perplexing to Muhammad; why had God not honoured him the same way? The prophet's inner pondering on this thought is capable of factoring imaginations and even 'revelations'. Muhammad only grasped the opinions of the people but not the revelation of the Holy Spirit which was uttered by Peter. Muhammad's confusion seemingly lies in the concept of Jesus' sonship.

\begin{tabular}{|c|c|c|}
\hline Description & Excerpt & Sura \\
\hline Not God & $\begin{array}{c}\text { "In blasphemy indeed are } \\
\text { those who say God is } \\
\text { Christ." }\end{array}$ & $5: 17$ \\
\hline Not the Son of God & $\begin{array}{c}\text { "The Christians call Christ } \\
\text { the son of Allah...Allah's } \\
\text { curse be upon them" } \\
\text { "It is not befitting to (the } \\
\text { majesty) Allah that he } \\
\text { should begat a Son" }\end{array}$ & $9: 30$ \\
\hline Not possessing divine & $\begin{array}{c}\text { "You (Allah) knows what's } \\
\text { attribute my heart, though I do } \\
\text { not know what is in yours" }\end{array}$ & \\
\hline Not crucified & $\begin{array}{c}\text { "They did not kill him or } \\
\text { crucified him" }\end{array}$ & $4: 116$ \\
\hline Like Adam & $\begin{array}{c}\text { "The similitude of Jesus } \\
\text { before Allah is as that of } \\
\text { Adam" }\end{array}$ & $3: 157$ \\
\hline
\end{tabular}

Muhammad is not at home with God begetting a son. When Muslims are asked who they say Jesus is; many often promptly reply with a limited explanation of his roles or with descriptions of what he is not. This is why the Islamic denial of the sonship of Jesus is portrayed in physical terms; "...Our Lord has not taken a consort or a son" (72:3). Meanwhile, the concept of 'sonship' has been used in the metaphorical sense severally in the Quran (2:177). The deliberate refusal

${ }^{37}$ Bruce A. Ware, God's Greater Glory: The Exalter God of Scripture and Christian Faith (Illinois: Crossway, 2004), 61.

${ }^{38}$ Swanson, "Thinking through Islam", 174. 
to apply the same understanding to Jesus is simply because Muslims will be open to explore the meaning of Jesus as a son on the basis on Christian terms - virgin birth and obedience.

Muhammad's stance on the person of Christ can be plausibly viewed as deliberate. He may have aware that the acknowledgement of the true identity of Jesus as Christ would put his own newly established religion in jeopardy. Muhammad further may have calculated that if Jesus was truly established to the people of Arabia as the Christ that He is, then, he becomes irrelevant, in fact, a nondescript personality. This insecurity is seen in the Islamic confession of faith, with the often reiteration "Muhammad is the Apostle of Allah". This observation prompted Muhammad to come up with a network of life-controlling principles as substitutes for the true place of Christ. He likely knew that with these human philosophies and principles, neither will man see the need for any so called 'saviour' nor will there be any yearning of knowing the true person of God as one who truly loves humankind and manifests himself through the person of Jesus Christ as one of the triune Godhead.

\section{Jesus' Crucifixion}

The Qur'an does not deny the Passion Week, but Islam has a theological argument against the death on the cross. This is because suffering is part and parcel of the early Muslim umma. It is commonly believed by Muslims that on Jesus' way to Calvary, God put someone else in place and took Jesus away. Cragg (1985) summarizes the common conclusion of Muslims; 'historically Jesus did not die, theologically he needs not to die, and morally he should not die'. ${ }^{39}$ This stance has tantalizing parallels to ancient Gnostic views of a substitute who died in place of Jesus, or that his body was crucified while his real body did not suffer (Robinson, 1977)..$^{40}$ Muslims, Sunnis in particular commonly claim that God is Almighty; therefore, He could not and will not allow his Prophet, Jesus to be crucified (Dudely, 1996). ${ }^{41}$ Since the idea of a complete defeat of a divine messenger is unthinkable, death is then seen as an enemy by Muslims.

On a contrary, the Bible plainly teaches that God, in love, offered up Jesus Christ on the cross for man's sin and raised Him again on the third day for man's justification. But the Qur'an says half no and half yes; this is more explicit in what Surat 19:33-34 states; Jesus says, "Peace be upon me the day I was born, the day I die and the day am being brought back alive." This clearly implies a real death and resurrection - but Muslims interpret Surat 4:157 as a counter-effect of the claim here that Jesus was taken to heaven without crucifixion and so he is expected to come again and die before the final Resurrection Day (a scenario that is not clear at all in the Qur'an). Many Islamic scholars in the attempt to settle the Quranic confusion of accepting the good Friday and denying the crucifixion strongly raise issue concerning of connection of other scriptures, especially the Bible.

Surat 3:55 says: "Behold! God said: O Jesus! I will take thee to myself and clear thee of falsehood and those who blaspheme; I will make those who follow thee superior to those who reflect faith, to the day of resurrection, then shall ye all return to me and I will judge between you of the matters wherein ye discipline. "The Arabic word "inni-mutawatteka" translated "I will take thee" is the point of controversy among several Islamic scholars (Cragg, 1973). ${ }^{42}$ Some argue that the word means death of sleep. They explained that Jesus did not die, instead He was just sleeping (Daniel,

${ }^{39}$ Kenneth Cragg, Jesus and the Muslim (London: George Allen and Unwin, 1985), 178.

40 J.M Robinson, ed. The Nag Hammadi Library in English (Leiden: E.J. Brill, 1977), 245.

${ }^{41}$ Dudely, "The Muslim Understanding of Jesus", 174.

${ }^{42}$ Kenneth Cragg, The Mind of the Qur'an: Chapters in Reflection (London: George Allen and Unwin, 1973), 203. 
1960). ${ }^{43}$ Some also explained that God took Jesus from the world but not through death. Yet, other claim God caused Jesus to die for three hours, then He raised Him to life and took Him to heaven; some even said it' seven hours (Hourani, 1999). ${ }^{44}$ The verb used (tawaffa) is associated with death in the other 25 uses of it in the Qur'an, three of them referring to Muhammad's actual death. How then is there argument when used in association with Jesus?

Surat 4, An-Nisa 157: "That they said (in boast), "we killed Christ Jesus the Son of Mary, the Apostle of God; but they killed him not nor crucify him, but so it was made it appear to them and those who differ therein are full of doubts with no certain knowledge but only conjecture to follow for of a surety, they will kill him not. From the above Sura came the Muslim's believe that Jesus was not killed, instead Allah cast the likeness of Jesus into another man - thus, Jesus was snatched up into heaven, while the other man was sacrificed. Meanwhile, the name of the other man is not provided. The comment of Shorrosh (1980) who is an Arab is noteworthy; "I have never known of any other meaning of "inni - mutaratteka" than death, within or without the Qur'an. ${ }^{45}$

Although Surat 4:157 states that Jews did not crucify Jesus, the Qur'an based on 3:55/48 would seem to allow that God somehow caused him to die and raised him again, despite the weight of Muslim standpoints to the contrary. With tawaffa in view, another way of the interpreting the Quranic material is to say that Jesus died, but only his body, not his soul. Jesus uses the same reasoning in Gospel according to Matthew: "Be not afraid of those who kill the body but are not able to kill the soul" (10:28). This interpretation might seem to favour Muslims more than Christians and is therefore contested, but then, the Qur'an used this kind of reasoning after the disastrous battle of Uhud with the words; 'say not of those who may be killed in the way of God that they are dead. Nay, they are alive, only you are not aware' (Surat 2:154). Jesus reminded Pilate of the same ultimate source of life and death; "you would have no power over me, unless it be give you from above" (John 19:11).

In the biblical account of Jesus' death, Peter represents the Islamic attempt to deny the necessity of the cross. For a while, Peter repudiated Jesus Christ. Peter, just like the Muslims thought at the late hour that Jesus would not and should not end his life on the cross. In Matthew 27:26, Jesus was condemned to death by an ecclesiastical authority for blasphemy, but since this is not a general reason to warrant death in the hand of Roman government, the Jewish leaders changed it that Jesus was plotting against Rome. With this central detail omitted, the Qur'an clearly denies the necessity and historicity of the cross (Hourani, 1991). ${ }^{46}$

Muhammad died within ten years after he moved from Mecca to Medina. He was buried in Medina in June 632 CE. The Qur'an affirmed that Christ did not die because he is a prophet of God. Even the traditional Muslim rejection of the crucifixion includes the intention of people to kill Jesus and his willingness to die. It is not by accident that Jesus was hung on the cross; it was not also by accident that He rose again. It was all part of God's plan to save a fallen humanity that cannot save itself - Genesis 22:8 (Kolawole, 2019). ${ }^{47}$ At the heart of this plan was 'grace'- "God made the one who did not know sin to be sin for us, so that we might become God's righteousness in Him" (2 Corinthians 5:21). Jesus stretched out his arm to hug the whole world on the cross, He

\footnotetext{
${ }^{43}$ Norman Daniel, Islam and the West: The Making of An Image (Edinburg: University Press, 1960), 167.

${ }^{44}$ Albert Hourani, A History of the Arab Peoples (Cambridge: MA: Harvard University, 1991), 25.

${ }^{45}$ Shorrosh Annis, Islam Revealed: A Christian Arab view of Islam (Nashville: Thomas Nelson and Sons, 1980), 3.

${ }^{46}$ Hourani, A History of the Arab Peoples, 26.

47 Kolawole Oladotun Paul, "God's Image in Man; A Biblical Perspective" American Journal of Biblical

Theology: Illuminating God's Word, April. Volume 20: 14, (2019).
} 
said it is finished (John 19:30). He fulfilled the covenant God promised humanity from the beginning of time - Gen 3:15 (Kolawole, 2019). ${ }^{48}$ Therefore, the burden of the interpretation for Christian is to demonstrate what Christ has accomplished through the crucifixion.

\section{Jesus' Eschatology}

The Hadith (collections of stories reported to have been told by Muhammad) ascribe an important role to Jesus at the End of Times. Paradoxically, this motif went along with an emphasis on Jesus' supposed ignorance as to the specific eschatological events. Jesus asks the angel Jibrīl (Gabriel) when the Hour will come, but Gabriel does not know it either (Khalidi, 2001). ${ }^{49}$ Comparing Jesus to other prophets is a characteristic feature in the Islamic description of Jesus. Apparently the statement of the gospel that even the Son does not know the Hour, but the Father alone (Mark 13:32, already mitigated in Matthew 24:36) was known to this eighth-century author, who ignores Jesus being addressed as Son and God's appellation as Father, but retains the notion of Jesus not knowing the End. An intra-Muslim polemic against chiliastic tendencies, e.g. in Shi'ite Islam, may have fostered this notion of Jesus not knowing the End.

Although widespread among Muslims, it is not clear that the Qur'an refers to Jesus' return. Sura 166/157; "(There is) not (one) of the People of the Book except (he) will most certainly believe in him before his death, and on the Day of Resurrection, he will be a witness against them." The vagueness is in the fact that the Quran is not emphatic on the personality who will be believed in, before whose death it will occur and who will be a witness against the Jews on the day of resurrection. Another Quranic verses commonly cited to support Jesus' return is 43:61. Meanwhile, the Arabic ilumun (knowledge) or alamun (sign) is not clear whether the subject is about a person (Jesus) or a thing (presumably the Qur'an) (Dudely, 1996). ${ }^{50}$

\section{Reflections}

With regard to shared beliefs, Christians and Muslims hold in common important truths that should be emphasized in the face of easily erected barriers. Both religions affirm the humanity of Jesus. This is a central truth of the New Testament Scriptures (John 1:9, 14; Hebrews 2:14, 17; 5:7-81) and Christian theology (Otunnaya \& Kolawole, 2021). ${ }^{51}$ Thus, the Christian faith and salvation are in no way diminished by fully acknowledging Jesus' humanity. The spirit that denies that Christ has come in the flesh is of the Antichrist (1 John 4:3-4). From a Christian viewpoint it must be stated even stronger: Jesus' humanity is seen as a clear demonstration of God's awesome love for his creatures. That the Creator becomes creature, suffers and dies is the supreme expression of love and might (Kolawole, 2019). ${ }^{52}$ Christians and Muslims affirm monotheism and reject tritheism. The confession of the Torah, "Hear O Israel, The Lord our God, the Lord is one" (Deuteronomy 5:4), is the Christian confession. On this point, one who truly values God's transcendence and his mystery will find it difficult to understand that God must be one and unique.

Time and again, the Qur'an warns the hearer that God has no son. Jesus is even taken to task by God: "Did you tell mankind: take me and my mother as two gods beside God?" (Sura 5:116). Of course the Islamic Jesus denies having said that. A typical Christian Arab rebuttal wonders at

${ }^{48}$ Kolawole Oladotun Paul, The Reality of God's Love for Mankind: A Sharp Lens on the Book of Genesis (Mauritius: Blessed Hope Publishing Company, 2019), 75.

49 Tarif Khalidi, The Muslim Jesus: Sayings and Stories in Islamic Literature (Cambridge, MA: Harvard University Press, 2001), 25.

${ }^{50}$ Dudely, "The Muslim Understanding of Jesus", 176.

${ }^{51}$ Otunnaya \& Kolawole, "The Relevance of John 1:1-18 For Contemporary Christians", 178.

52 Kolawole, The Reality of God's Love for Mankind: A Sharp Lens on the Book of Genesis, 85. 
what time God may have said this to Jesus: was it before Muhammad, in which case Jesus would be with God, and apparently divine? Or on the Last Day, which presupposes in Muhammad or in the Qur'ān a clairvoyance of things that have not yet happened? The denial of Jesus' claim to be God obviously is a platform to present Jesus as a moral sage who went around teaching people to love one another and get along while respecting diversity. Far from drawing attention to his personae; they suppose He only meant to spread love for humanity through service and sacrifice (Howard, 2009)..$^{53}$ While it is certainly true that Jesus loves humanity and upheld the necessity of serving others, it is absolutely insupportable to say that he made no grand claims about himself. All the earliest biographical books about Jesus affirmed that he claimed to be nothing less than God's own divine son (Fieldman, 1986; Maier, 1995; Kostenbeger, 2009). ${ }^{54}$

Islam explains Jesus' sonship in physical terms, suggesting "adoptionism". Meanwhile, the divinity of Jesus is not the result of God taking to himself a human being, Jesus the son of Mary who would become God's son. The language of "beget" and "begotten" simply mean the Eternal Son of God became man, without renouncing his divinity he acquired a human nature, so as to become truly and fully human. The Sonship of Jesus in the New Testament may be compared to the relation between God and his Word in the Qur'an: God's Word is eternal and uncreated, yet distinct from God. It has "descended" on Muhammed and found verbal expression in the Qur'an, yet, it remains in heaven. Muslims lack consistency when they accuse Christians of polytheism for believing something that is structurally parallel. The eternal Logos of God did not come to us in the form of a book, but as the God-man, the Lord who took the condition of a servant (Boer, 2006). ${ }^{55}$ Nicolaides $(2021, \mathrm{a} / \mathrm{b})$ explains that the early Church had its roots in Alexandria and spread into the surrounding region from there, including Arabia. In addition the same author stresses that Jesus the Christ is the Theanthropos or God-man, unlike any other. The redeemer of the world.

The titles of the Jesus in the Quran obviously show him as an esteemed prophet and messenger with unique traditions that Muslim traditions could not exhaustively explain. The virgin birth is only peculiar to Jesus among all the apostles of Allah; He alone is the Spirit and Word of God. He is also the only one who is without sin, not even Muhammad. Yet, Jesus is human and servant, just like all other prophets. This Quranic portrait falls short of the testimony of the Gospels where Jesus is indeed a prophet and messenger, but more than both. Jesus is therefore the Eternal Word and the uncreated Son - God's Incarnate. His servanthood is genuine and his perfect obedient service leads him to secure the salvation of his people from their sins.

The source of the Islamic narrative is not Christian; Quispel even argued that much of it does not even belong to apocryphal or oral sayings of Jesus. Some sayings of Jesus in Islamic garb, dating from seven or more centuries after the gospels, can be traced to Christian sources and even, according to some scholars, to unknown sayings of Jesus himself (Quispel, 2008), ${ }^{56}$ but the origin of this story is not Christian. Versions of it can be found both in the Babylonian Talmud, the

53 Jeremy Royal Howard, Understanding Jesus (Tennessee: B \& H Publishing Group, 2009), 241-242.

54 Louis H. Feldman, Gōhei Hata, eds. Josephus, Judaism and Christianity (Leiden: Brill , 1987), 54. Paul L. Maier, Josephus, The Essential Works: a Condensation of Jewish Antiquities and The Jewish war (Grand Rapids, Michigan: Kregel Academic, 1995), 284. Andreas J. Kostenberger, Kellum L. Scott, Charles L. Quarles, The Cradle, the Cross, and the Crown: An Introduction to the New Testament Tennessee: B \& H Publishing Group, 2009), 104-105.

${ }^{55}$ Harry R. Boer, A Brief History of Islam (Ibadan: Day Star Press, 2006), 17.

${ }^{56}$ Gilles Quispel "The Muslim Jesus," in Gnostica, Judaica, Catholica: Collected Essays of Gilles Quispel, ed. Johannes van Oort (Leiden: Brill, 2008) 627-62. Quispel regards the Gospel of Thomas as an eminent source of "the Muslim Jesus" but sees the influence of this gospel in so many places that it detracts from his methodology. 
principal document of rabbinic Judaism, and in the Palestinian Talmud. The Islamic narrative story betrays a Babylonian Sitz im Leben. The search for pre-Islamic sources of the Islamic Jesus may have had a polemical thrust in the past, aimed at proving that the Islam contained nothing new, but this search should nowadays be conducted in historical perspective.

\section{Conclusion}

History attested to the existence of Jesus, non-Christians and others who lived during that age witnessed that wonderful time in history when the God incarnate lived among men (Aremu \& Malomo, 2015). ${ }^{57}$ This event happened; it was recorded, discussed and affirmed about five hundred years (c. $500 \mathrm{CE}$ ) before a man appeared in the space of time with a different philosophy about mankind and the means to salvation. Muhammad taught that salvation was not given but earned. Since this teaching was contrary to what men knew; he then needed to situate his teachings with an already greatly established figure whose identity would give credence to his message. He knew full well that the diehard fan of this true faith is long gone and that ignorance dwelled in the land where he would propagate his teachings. Muhammad then had to reconstruct the life of Jesus, fitting into his own personal and claimed divine agenda. This answers why the Quranic stories about Jesus fit in more or less as a redacted work.

Although the Quran recognizes the divine and human nature of Jesus, the latter was explicitly minimized. The seeker of the true historical Jesus cannot turn to the Quran (Dunn, 1977; 2003).58 Explicit in this work is the fact that the Quran records no sermon or parable, none of Jesus' gentle words to the poor and dispossessed, none of his outing challenges to the authority of his day. But then, the Muslims veto the cross even though the rest of mankind regardless of their religious commitments, acknowledged the historicity of Jesus' 'cross event'. The Quran simply presents the life of Jesus as a great prophet worthy of honour. How and why should Jesus' life be honoured? The Quran is not explicit; rather it looks more like an edited version of the biblical account. However, the element that the people of Jesus' day wanted to kill him and that he was willing to die reflects in the Quran, yet Muslims deny his resurrection from the dead.

Muslims have a very optimistic doctrine of man but a different understanding of sin which does not allow the law to act as a teacher that will lead one to Christ. An objective study of Jesus in the Bible and Quran reveals the Lordship and saving grace through Christ alone. To speak coherently about these things with a Muslim interlocutor requires a Christian to go deep into scriptures and the Christian theological tradition. God's power was shown not by raising Jesus before his work on the cross as traditional Muslim interpretation would affirm. Rather, God demonstrate his power by raising Christ after his work was done on the cross. In view of this, Muhammad presented the people of Arabia with what is partial truth according to the Christian faith, following the opinion of the people that Jesus is a prophet (Matthew 16:13) other than the true identity of Jesus Christ by the revelation of God's Spirit which reveals Jesus as more than a prophet; Yet to Christians, "Jesus is Christ, the Son of the Living God."

\section{References}

Ali, M. (1999). Islam Reviewed, Fort Myers: Fish House Publishing,

${ }^{57}$ Aremu and Malomo, Christian Theology in African Context, 37-38.

58 James D.G. Dunn, Jesus Remembered; Volume 1, Christianity in the Making (Grand Rapids: Eerdmans, 2003). James D.G. Dunn, Unity and Diversity in the New Testament: An Inquiry into the Character of Earliest Christianity (Philadelphia: Westminster, 1977). 
Annis, S. (1980). Islam Revealed: A Christian Arab view of Islam, Nashville: Thomas Nelson and Sons.

Aremu T. \& Malomo, E. O. (2015). Christian Theology in African Context, llorin: Amazing Grace Prints.

Boer, H. R. (2006). A Brief History of Islam, Ibadan: Day Star Press.

Cahill, T. (1998). The Gifts of the Jews: How a Tribe Desert Nomads Changed the Way Everyone Thinks and Feels, Doubleday: Nan A. Talase.

Caner, E. M. \& Caner, E. F. (2002). Unveiling Islam, Nassarawa: Evangel Publishers.

Cragg, K. (1973). The Mind of the Qur'an: Chapters in Reflection. London: George Allen and Unwin.

Cragg, K. (1985). Jesus and the Muslim, London: George Allen and Unwin.

Cragg, K. (1995). Readings in the Qur'an, London: Fount Paperbacks.

Daniel, N. (1973). Islam and the West: The Making of An Image, Edinburg: University Press.

Dudely, W. J. (1996). The Muslim Understanding of Jesus, Word and World, XVI(2), Spring.

Dunn, J. D. (1977). Unity and Diversity in the New Testament: An Inquiry into the Character of Earliest Christianity, Philadelphia: Westminster.

Dunn, J. D. (2003). Jesus Remembered; Volume 1, Christianity in the Making, Grand Rapids: Eerdmans.

Feldman, L. H., Gōhei Hata, eds. Josephus, (1981). Judaism and Christianity, Leiden: Brill.

France, R.T. (2008). Matthew: Tyndale New Testament Commentaries, Michigan: IV P.

Geoffrey, F. (1960). Parrinder Jesus in Quran, London: Oxford One World Publication.

Gilles, Q. (2008). "The Muslim Jesus," in Gnostica, Judaica, Catholica: Collected Essays of Gilles Quispel, ed. Johannes van Oort. Leiden: Brill.

Hourani, A. (1991). History of the Arab Peoples, Cambridge: MA: Havard University.

Howard, J.R. (2009). Understanding Jesus, Tennessee: B \& H Publishing Group.

Jacob, P. O. \& Kolawole, O. P. (2020). Is the Bible the Word of God? A Theo-Apologetical Rethink, Pharos Journal of Theology, 101(4).

Khalidi, T. (2001). The Muslim Jesus: Sayings and Stories in Islamic Literature, Cambridge, MA: Harvard University Press. 
Kolawole, O. P. (2019). "A Critical Examination of the Concept of Righteousness in Matthew," Asia-Africa Journal of Mission and Ministry, 20, August 31. Hwarangro Nowon-gu, Seoul: Mission and Society Research Institute, Sahmyook University.

Kolawole, O. P. (2019). God's Image in Man; A Biblical Perspective, American Journal of Biblical Theology: Illuminating God's Word, April. 20(14).

Kolawole, O. P. (2019). The Reality of God's Love for Mankind: A Sharp Lens on the Book of Genesis, Mauritius: Blessed Hope Publishing Company.

Kolawole, O. P. (2020). "The Central Theme of John's Gospel and the Christian Community", Asia Pacific Journal of Academic Research in Social Sciences, Vol. 5 [May] No. 1. Batangas City, Philippines: Lyceum of the Philippines University.

Kolawole, O. P. (2021). "Proclaiming the Christian Gospel to Muslims", John W. Carter [Ed.], Light in a Once Dark World: Contemporary Issues in Nigerian Christianity, Volume IV, Hayesville: American Journal of Biblical Theology.

Kostenberger, A. J., Scott, K. L. \& Quarles, C. L. (2009). The Cradle, the Cross, and the Crown: An Introduction to the New Testament, Tennessee: B \& H Publishing Group.

Maier, P. L. (1995). Josephus, The Essential Works: a Condensation of Jewish Antiquities and The Jewish war, Grand Rapids, Michigan: Kregel Academic.

McDowell, J.J. (2002). Understanding Islam and Christianity: Belief that Separates us and How to talk about them, Oregon: Harvest House Publications.

Michael, C. (1983). Muhammad, Oxford: University Press.

Moucarry, C.G. (2002). The Prophets and the Messiah: An Arab Christian Perspective on Islam and Christianity, Illinois: Inter Varsity Press.

Neal, R. (1991). Christ in Islam and Christianity, Oxford: Oxford University Press.

Nicolaides, A. (2021a). Reflections on the City of Alexandria and the growth of the early Christian faith, Pharos Journal of Theology, 103 DOI: 10.46222/pharosjot.10310

Nicolaides, A. (2021b). Investigating the Holy Eucharist and the term 'people of God' according to the Eastern Orthodox Church, Pharos Journal of Theology, 102.

Nicolaides, A. (2010). 'The Laos tou Theou - an orthodox view of the "people of God"', HTS Teologiese Studies/Theological Studies, 66(1), DOI:10.4102/hts.v66i1.372.

Obasola, K. E., Oderinde, O. A. \& Akanni, A. A. (2020). "Islam's Response to the Quest for Peace, Orderliness and Well-being in Nigeria", A Festschrift in Honour of Prof. Kamaldeen Abdulazeez Balogun. ljebu Ode: Alamsek Gen Concept.

Otunaya, A. \& Kolawole, O. P. (2021). The Relevance of John 1:1-18 For Contemporary Christians, Vidyajyoti Journal of Theological Reflection, 85(3) March.

Robinson, J.M. (1977). The Nag Hammadi Library in English, Leiden: E.J. Brill. 
Schumann, O. H. (2002). Jesus the Messiah in Muslim Thought, Delhi: ISPCK.

Swansea, M. N. (2002). Thinking through Islam, Word and World, 22(3), Spring.

Ware, B. A. (2004). God's Greater Glory: The Exalter God of Scripture and Christian Faith, Illinois: Crossway.

Zaka, A. \& Coleman, D. (2004). The Noble Quran's Teachings in the Light of the Holy Bible, New Jersey: R and R Publishers.

Zwemer, S.M. (1912). The Muslim Jesus, Edinburgh: Anderson and Femier. 